\title{
Introduction to the Thematic Issue of the Siberian Federal University Journal, the Humanities series, in the "History and Theory of Art" Research Field
}

\author{
Natalia P. Koptseva* \\ Siberian Federal University \\ Krasnoyarsk, Russian Federation
}

Received 04.05.2020, received in revised form 05.06.2020, accepted 15.06.2020

\begin{abstract}
The introduction precedes the publication of the results of scientific research in the field of history and theory of art, as well as in the field of the most important conceptual problems of modern humanities and social sciences. The major current problems in the field of world and Russian art are considered, the main trends in the development of modern humanities and social sciences are determined. The introduction presents a theoretical position that should reveal the methodological approaches to the analysis of works of visual and musical art. The research is based on the basic principles of the modern theory of art, which states that a work of art is always the result of complex interaction in two forms: 1) the result of an interaction of an artist (master) and an art material; 2) the result of the interaction of a work of art as a material thing and a recipient (viewer, listener). The task of an art historian is to become an intermediary between the recipient and the work of art. This mediation in world philosophy is called maieutics. The maieutic function of the humanities and social sciences is revealed in all the studies, the results of which are published in this thematic issue.
\end{abstract}

Keywords: humanities, theory of art, history of art, work of art, recipient.

Research area: theory and history of art, theory and history of culture.

Citation: Koptseva, N.P. (2020). Introduction to the thematic issue of the Siberian Federal University Journal, the Humanities series, in the "History and theory of art" research field. J. Sib. Fed. Univ. Humanit. Soc. Sci., 13(6), 834-837. DOI: 10.17516/1997-1370-0609.

\footnotetext{
(C) Siberian Federal University. All rights reserved

* Corresponding author E-mail address: decanka@mail.ru ORCID: 0000-0003-3910-7991
} 
The history and theory of art as separate areas of the humanities and social sciences appear at the end of the 18th century, primarily in aesthetic and philosophical treatises, which reveal the purpose of art as a whole, build a hierarchy of different types of arts, determine the differences between art and religion, art and craft art and philosophy. In the first third of the 19th century, the great German philosopher G.W.F. Hegel defines art as a manifestation of absolute spirit along with religion and philosophy. In his aesthetic philosophy, Hegel places art on the first step of ascending to the absolute spirit, and defines a work of art as a sensory phenomenon of essence. Different types of art in different ways allow the entity to manifest itself. Therefore, within art, there is also a hierarchy of various types of art, on top of which is literature (Zhukovsky, Koptseva, 2004).

In contrast to Hegel, F. W. J. Schelling understood that absolute spirit cannot be adequate to a logical rational form of philosophy and that the highest form of cognition is just art combining both conscious and unconscious principles. Schelling's philosophy of art shows that art gives the form to mythology, and mythology translates the unity of the subjective and objective spirit as fully as possible, without violating the measure of subjective-human in this unity.

For Russian art criticism, both traditions Hegel's and Schelling's ones- were equally typical. However, both traditions, of course, were transformed and acquired their own characteristics. Thus, Hegel's understanding of art as a sensory phenomenon of essence led to a huge discussion about the social purpose of art, the social role of the artist in the transformation of reality, the need to contribute to changing all aspects of public life for the better (Leshhinskaya, Petrova, 2019). All types of art are considered here according to the degree of their social purpose (Pchelkina, 2017).

Schelling's tradition was reproduced in the works of Vladimir Solovyov, Russian religious philosophy of the Silver Age, in manifests of "art for art's sake", in pedagogical innovations, where teaching art skills and studying masterpieces of world art culture accompanies a child and then an adult student, where the study of art is considered a necessary element of modern education.

In the modern era, a number of transformations are taking place both in terms of art itself and its research. Three basic features of modern culture - mass, decentralization and marketing - change both the being of works of art and methodological approaches to the studies of the essence of works of art and the social being of art (Avdeeva et al., 2019; Amosova et al., 2019). Contemporary art is most consistent with the romantic definition of artistic style in Hegelian aesthetics, where the material side of a work of art is always less than the meaning implied in it. In such material minimalism, the role of the recipient (viewer or listener) grows immeasurably, which is necessarily included in the game proposed by the master, and contributes to the creation of an artistic image, where most of the creativity is reserved for the recipient, but not for the author. Contemporary art presupposes compulsory co-creation involving the viewer, therefore the theory of art goes where this viewer is present - to museums, galleries, the mass media, social space, and the theory of art is transformed into maieutics, into a way of creating an artistic image for which the viewer needs help with starting the process of creating an artistic image (Bralkova et al., 2015; Kistova et al., 2018; Koptseva et al., 2018; Semenova, 2012).

This maieutic function of art theory is presented in a number of articles of this thematic issue. The subject of our authors' research are visual and musical works of art. The creators of these works of art are internationally known artists and masters who are important in the context of the Krasnoyarsk regional art culture. Our researchers analyse masterpieces and works of art that are important for a certain category of recipients. Sometimes, in one art history article, relevant regional artistic practices and the experience of the existence of a great masterpiece in a regional context are combined.

An important element of the thematic issue is the study on the role of universities in today's changing world. The discussion about the need for the humanities, theory and history of art necessarily involves an understanding 
of the purpose of the university in the context of this discussion. The expert function of university scientists should not focus on current pressing problems, a modern university creates meanings and concepts that did not exist before, and forms the agenda itself, making relevant not only material life support, but also the quality of the inner life of a person who has come to university to change .
The Journal's team, which was preparing this thematic issue for publication, sincerely welcomes its readers and hopes that the publication of scientific articles will cause fruitful and lively scientific discussions. A number of articles have a pronounced discussion character, and we hope that the responses to these articles will also take the form of a scientific publication open for a dialogue.

\section{References}

Amosova, A.A., Koptseva, N.P., Sitnikova, A.A., Seredkina, N.N., Zamaraeva, Yu.S., Kistova, A.V., Reznikova, K.V., Kolesnik, M.A., Pimenova, N.N. (2019). Ethnocultural identity in the works of Krasnoyarsk artists. In J. Sib. Fed. Univ. Humanit. soc. sci., 12(8), 1524-1551. DOI: 10.17516/1997-1370-0463

Avdeeva, Yu.N., Degtyarenko, K.A., Metlyaeva, S.V., Pchelkina, D.S., Fil'ko, A.I., Koptseva, N.P., Shpak, A.A. (2019). Dynamics of Krasnoyarsk urban space in the early 21 st century. In J. Sib. Fed. Univ. Humanit. soc. sci., 12(6), 953-974. DOI: 10.17516/1997-1370-0434.

Bralkova, A., Gerasimova, A., Govoruxina, Yu., et other. (2015). Novaya art-kritika na beregax Eniseya [New art criticism on the banks of the Yenisei]. Krasnoyarsk, izdatel 'stvo Sibirskogo federal'nogo universiteta.

Kistova, A., Pimenova N., Bukova M. (2018). Sovremennoe sostoyanie dekorativno-prikladnogo iskusstva e'venkov - korenny'x narodov Sibirskoj Arktiki [The current state of decorative and applied art of Evenki - indigenous peoples of the Siberian Arctic]. In Severny'e Arxivy' i E'kspedicii [Northern Archives and Expeditions], 2. (1), 49-56.

Koptseva, N., Reznikova, K., Razumovskaya, V. (2018). The construction of cultural and religious identities in the temple architecture. In Journal of Siberian Federal University. Humanities \& Social Sciences, 7 (11), 1021-1082.

Leshhinskaya, N., Petrova, K. (2019). Dekorativno-prikladnoe iskusstvo korennykh malochislenny'kh narodov Severa Krasnoiarskogo kraia: kostoreznoe iskusstvo [Decorative and applied art of the indigenous peoples of the North of the Krasnoyarsk Territory: bone carving art]. In Severnye Arkhivy i Ekspeditsii [Northern Archives and Expeditions], 3 (1), 72-79.

Pchelkina, D. (2017). Iskusstvo kak oblast' konstruirovaniia gendera i gendernoi reprezentatsii [Art as an area of gender construction and gender representation]. In Sibirskii antropologicheskij zhurnal [Siberian Anthropological Journal], 4 (12), 21-34.

Seredkina, N., Kistova, A., Pimenova, N. (2019). Tri kartiny Edvarda Munka: filosofsko-iskusstvovedcheskii analiz tsikla "Friz zhizni" [Three paintings by Edward Munch: philosophical and art history analysis of the cycle "Frieze of life"]. In Sibirskii antropologicheskij zhurnal [Siberian Anthropological Journal], 4 (12), 49-64.

Semenova, A. (2012). Vizual'naia kul'tura modernizirovannogo sotsiuma. In Vestnik Volgogradskogo gosudarstvennogo universiteta. Seriia 7: Filosofiia. Sotsiologiia i sotsial'nye tekhnologii [Bulletin of Volgograd State University. Series 7: Philosophy. Sociology and social technology], 3 (18), 145-149.

Zhukovsky, V.I., Koptseva, N.P. (2004). Propozitsii teorii izobrazitel'nogo iskusstva [Propositions to the theory of fine art]. Krasnoyarsk, Krasnoyarsk State University. 


\title{
Вступительная статья к тематическому выпуску журнала Сибирского федерального университета «Гуманитарные науки» по научному направлению «История и теория искусства»
}

\section{Н.П. Копцева}

Сибирский федеральный университет

Российская Федераџия, Красноярск

\begin{abstract}
Аннотация. Введение предваряет издание результатов научных исследований в области истории и теории искусства, а также в области важнейших концептуальных проблем современных гуманитарных и социальных наук. Рассматриваются основные актуальные проблемы в области мирового и российского искусствоведения, определяются основные тенденции развития современных гуманитарных и социальных наук. Во введении представлена теоретическая позиция, которая должна раскрыть методологические подходы к анализу произведений изобразительного и музыкального искусства. В основе исследований лежат базовые положения современной теории искусства, утверждающей, что произведение искусства всегда представляет собой результат сложного взаимодействия в двух формах: 1) результат взаимодействия художника (мастера) и художественного материала; 2) результат взаимодействия произведения искусства как материальной вещи и реципиента (зрителя, слушателя). Задача ученого-искусствоведа - стать посредником между реципиентом и произведением искусства. Это посредничество в мировой философии носит название «майевтика». Майевтическая функция гуманитарных и социальных наук раскрывается во всех исследованиях, результаты которых опубликованы в данном тематическом выпуске.
\end{abstract}

Ключевые слова: гуманитарные науки, теория искусства, история искусства, произведение искусства, реципиент.

Научная специальность: 17.00.00 - теория и история искусства, 24.00.00 - теория и история культуры. 